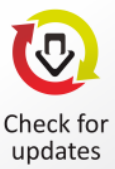

updates

Article Type: Research Paper

\title{
Whistleblowing Intention, Personal Cost, Organizational Commitment and Fraud Seriousness Level
}

\author{
Mirna Indriani ${ }^{1 *}$, Aida Yulia ${ }^{1}$, Nadirsyah $^{1}$, Lisa Pira Ariska $^{1}$
}

\begin{abstract}
This study aims to investigate whether personal costs, seriousness level of fraud and organizational commitment play a role in influencing whistleblowing intentions. It is also intended to prove whether organizational commitment has a mediating effect on the relationship among personal costs, seriousness level, and whistleblowing intentions. The research subjects comprise of civil servants or contract employees of Government Institutions of Regencies/Cities in Aceh Province, Indonesia. The hypotheses were tested on 103 respondents who were selected using convenience sampling method. The data were collected using survey questionnaires sent via online using Google Form from May to July 2017. The data were analyzed using Structural Equation Modeling-Partial Least Square (SEM-PLS). The results of this study showed that personal costs and seriousness level of fraud influenced whistleblowing intentions. Nevertheless, it appeared that organizational commitment did not influence whistleblowing intentions. This study also proved that organizational commitment did not have a mediating effect on the relationship among personal costs and level of seriousness and whistleblowing intentions.
\end{abstract}

KEYWORDS: whistleblowing intentions; personal cost; organizational commitment; seriousness level of fraud

\section{Introduction}

Whistleblowing is a term used in sports which depicts a referee blowing his/her whistle to stop a player who makes a foul. In the context of an organization, whistleblowing indicates a way which can be used to stop a foul or fraud occurring in an organization. Currently, institutions are encouraged to develop a whistleblowing policy as a part of their internal control system (Brennan \& Kelly, 2007; Hooks, Kaplan, \& Schultz, 1994; Miceli, Near, \& Schwenk, 1991), even as a wider movement to make these institutions more transparent and accountable (Gobert \& Punch, 2000) or to prevent a country from suffering from possible severer losses and law breaches which may occur (Rustiarini \& Sunarsih, 2008).

In accounting research, researchers agree to define whistleblowing as the 
Indriani, Yulia, Nadirsyah, \& Ariska

Whistleblowing Intention, Personal Cost, Organizational Commitment and Fraud Seriousness Level

action of revealing by a (former or current) member of an organization regarding an individual or organization's illegal, immoral or unlawful practices (Ayers \& Kaplan, 2005; Keenan, 2000; King, 1997; Miceli \& Near, 1984; Miceli, Near, Rehg, \& van Scotter, 2012; Near \& Miceli, 1996). The parties revealing or reporting these illegal practices are known as whistleblowers (Jeon, 2017; Sweeney, 2008)

Some studies found that whistleblowing is the most effective way to deal with fraud (Alam, 2014; Rizki Bagustianto \& Nurkholis, 2012; Dyck, Morse, \& Zingales, 2010; Said, Alam, Mohamed, \& Rafidi, 2017; Sweeney, 2008). The effectiveness of whistleblowing in revealing financial statements fraud is acknowledged by accountants and regulators not only in the United States, but also in other countries (Miceli, Near, \& Dworkin, 2008).

One's Intention or interest to do this whistleblowing or to become a whistleblower is a hard decision to make (Brennan \& Kelly, 2007) and it involves highly complicated processes (Miceli, 2004). The factors which influence the Intention to do whistleblowing , among other things, are: personal cost (Alam, 2014; Aliyah, 2015; Alleyne, Hudaib, \& Pike, 2013; Bagustianto \& Nurkholis, 2012; Hanif \& Odiatma, 2017; Lestari \& Yaya, 2017; Libriani \& Utami, 2015), fraud seriousness level (Ahmad, Smith, \& Ismail, 2013; Ahmad, Yunos, Ahmad, \& Sanusi, 2014; Aliyah, 2015; Ayers \& Kaplan, 2005; Bagustianto \& Nurkholis, 2012; Hanif \& Odiatma, 2017; King, 1997; K. M. King, 2003; Miceli \& Near, 1985), communication channel (Yuswono \& Hartijasti, 2018), and organizational commitment (Ahmad, Smith, \& Ismail, 2012; Aliyah, 2015; Bagustianto \& Nurkholis, 2012; Husniati, Hardi, \& Wiguna, 2017; Lestari \& Yaya, 2017; Wahyuningsih, 2016).

The personal cost is the whistleblower's perception of retaliation risk or sanction to be received for doing the whistleblowing. The greater an individual's perceived personal cost, the less likely this individual to be interested in doing the whistleblowing (Bagustianto \& Nurkholis, 2012; Schultz, Johnson, Morris, \& Dyrnes, 1993) or they have a negative relationship (Alleyne, Charles-Soverall, Broome, \& Pierce, 2017). Nevertheless, some studies found that personal cost does not affect whistleblowing intention (Bagustianto \& Nurkholis, 2012; Hanif \& Odiatma, 2017; Setyawati, Ardiyani, \& Sutrisno, 2015).

Fraud seriousness level is the materiality level of a fraud occurring in an institution. Any member noticing suspected fraud will be more likely to do the whistleblowing if the fraud is serious or material (Miceli \& Near, 2005). Some studies find that fraud seriousness level influences whistleblowing intention (Bagustianto \& Nurkholis, 2012; Cassematis \& Wortley, 2013; Hakim, Subroto, \& Andayani, 2017; Setyawati et al., 2015). Yet, some other studies find the opposite (Alleyne et al., 2017; Hanif \& Odiatma, 2017).

A strong organizational commitment within an individual will make them try their best to achieve the institution's predetermined goals (Setyawati et al., 2015). Previous studies find a gap on this topic, i.e., some researchers find that organizational commitment has an influence on whistleblowing intention (Bagustianto and Nurkholis, 2012; Husniati et al., 2017) and some others find that organizational commitment has no influence on whistleblowing intention (Lestari \& Yaya, 2017; Setyawati et al., 2015). 
Indriani, Yulia, Nadirsyah, \& Ariska

Whistleblowing Intention, Personal Cost, Organizational Commitment and Fraud Seriousness Level

This gap found by previous studies motivates the researchers to conduct this study, particularly by observing such variables as personal cost, fraud seriousness level and organizational commitment on whistleblowing intention. In this study, the organizational commitment variable was treated as an intervening variable, assuming that personal cost or fear of retaliation level would be lower if an individual did the whistleblowing for having high commitment. Also in this study, the organizational commitment was treated as an intervening variable between fraud seriousness level and whistleblowing intention, expecting that the high commitment would influence an individual to report fraud regardless of its size. Treating the organizational commitment variable as an intervening variable made this study different from previous studies (Lestari \& Yaya, 2017).

The research was conducted in regency/municipality government institutions in Aceh Province with employees, both contract ones and civil servants, working at the government institutions of regencies/municipalities in Aceh Province as the respondents. Aceh Province consisted of 23 regencies and municipalities. All these regencies/municipalities and the province itself since 2016 had obtained Reasonable Without Exception (RWE) opinion. Despite obtaining RWE opinion from BPK, it is not necessarily impossible that fraud would not occur (BPK Perwakilan Provinsi Aceh (BPK Representative for Aceh Province), 2017). For example, in 2017 the total state losses resulting from corruption case was Rp35 billions, and this number increased significantly in 2018 to Rp398 billions. The swindle was committed to APBD (regional budget), and Special Autonomy or Otonomi Khusus (Otsus) funds under the pretext of requesting commitment fee in each project, bribery for licensing, and mark-up for procuring goods and services (Mukhtar \& Maharani, 2018). The culprits of these corruptions in Aceh were from executive boards, private and companies (Nashrullah, 2019).

The phenomenon of a massive number of frauds has led to the need for conducting research on whistleblowing system which can be used as an early warning in disclosing fraud, namely through whistleblowing. Not many studies have been conducted on whistleblowing in Indonesia. Thus not many empirical shreds of evidence are available yet to be used in enriching the theories people can refer to in solving the existing problems. This phenomenon of a large number of frauds shows that many weaknesses are still there in the practical world. Thus it is necessary to conduct a study on the factors which influence whistleblowing which can be used as an early warning for any organization to deal with any possible fraud.

\section{Literature Review and Hypotheses Development}

\section{The Theory of Prosocial Behavior}

Theory of prosocial behavior is the one used by researchers to explain what whistleblowing is conceptually and empirically (Alleyne et al., 2013; Brennan \& Kelly, 2007; Brief \& Motowidlo, 1986; Miceli \& Near, 1988). Prosocial behavior is defined as the behavior which is performed: (a) by members of an institution; (b) directed toward 
Indriani, Yulia, Nadirsyah, \& Ariska

Whistleblowing Intention, Personal Cost, Organizational Commitment and Fraud Seriousness Level

an individual, group, or institution; and (c) to achieve the individual, group, or institution's welfare (Brief \& Motowidlo, 1986).

Whistleblowing is considered as a positive social behavior (Miceli et al., 2008) by people in general since a whistleblower can put an end to errors or fraud, intended to provide benefits to the people within or beyond the institution (Ahmad, 2011). This theory is the one which explains whistleblowing as a mechanism for internal and social control (Vinten, 1996). Dozier and Miceli (1985) also explains that whistleblowing is a prosocial behavior which involves altruistic and egoistic motives. Dozier and Miceli's opinion is not different from Ahmad (2011) who suggests that whistleblowing is not necessarily altruistic in nature, rather to some extent, a whistleblower might also have a motive of obtaining personal benefit or welfare.

In particular, the prosocial approach of whistleblowing is based on Latane and Darley's (1968) work on observer intervention model. This model states that an observer will make a response by offering assistance under the emergency circumstance. There are five steps of deciding to have whistleblowing behavior, and each step is highly critical in making the whistleblowing decision. These five steps include: (1) observer should be aware of the incident; (2) observer should decide that the incident is emergency; (3) observer should decide that he/she is responsible for assisting; (4) observer should choose the right assistance method, and 5) observer applies the intervention (Latane \& Darley, 1968). These are the five steps in making ethical decisions for informant candidates and thus highlighting the ethical dilemma inherent to the decision to do the whistleblowing (Brennan \& Kelly, 2007).

According to Brief and Motowidlo (1986), the theory of prosocial behavior has antecedent variables which are divided into two parts. The first one is individual antecedent, i.e., the aspect coming from an individual (Brief and Motowidlo, 1986). This is despite the many debates on whether humans are biologically more likely to behave prosocially (Campbell, 1979; Wispé, 1972). Hoffman (1981) collects many sociobiological and psychological evidence which support that altruism, at least, is a part of human's basic characters. Altruism is the trait of putting others' interest first. An example of the individual antecedent is an individual's ability in believing justice standards and an individual's commitment to a social environment. The second one is contextual antecedent, i.e., the aspect from an institutional and environmental context of the way moral reasonings such as norm factors, group cohesivity, role model, leadership style, organizational climate, pressure and, organizational commitment work (Brief \& Motowidlo, 1986).

\section{Whistleblowing Intention}

The Intention is a strong wish to do something which comes from within oneself (Kreshastuti \& Prastiwi, 2014). The intention will affect behavior since it should occur first before doing any behavior. With no Intention, this behavior can never occur. The intention may change as time changes. The wider the time interval, the more likely for this Intention to change (Hanif \& Odiatma, 2017). 
Indriani, Yulia, Nadirsyah, \& Ariska

Whistleblowing Intention, Personal Cost, Organizational Commitment and Fraud Seriousness Level

Whistleblowing Intention is different from actual whistleblowing since interest occurs before performing the actual whistleblowing, or in other words whistleblowing intention is needed to make the actual whistleblowing occur (Winardi, 2013). The decision to perform actual whistleblowing is also about whether to report a wrongful action or not, and it depends on the available alternative and whether the benefits received from the whistleblowing are greater than the costs suffered (Graham, 1986). The indicators used to measure whistleblowing intention are (Alleyne et al., 2017; Alleyne, Haniffa, \& Hudaib, 2016; Nayir \& Herzig, 2012): 1) perception of behavior, i.e., one's view of whistleblowing, is the action ethical or not; and 2) reporting channel such as internal reporting, external reporting, and anonymous reporting, i.e., the offense is reported to either internal or external parties or a trustworthy hotline.

\section{Influence of Personal Cost on Whistleblowing Intention}

Theory of prosocial behavior assumes that a person will do something for others to achieve their own, group or institution's welfare (Brief \& Motowidlo, 1986). One of the positive social behavior forms is whistleblowing (Miceli et al., 2008) since a whistleblower can put an end to errors or fraud to give benefits (Ahmad, 2011). Thus whistleblowing can be used as an internal and social control mechanism (Vinten, 1996). The theory of prosocial behavior has some antecedent which can be viewed from both individual and contextual perspectives (Brief \& Motowidlo, 1986). From an individual perspective, personal cost is the determinant factor of a decision to be a whistleblower. According to Graham (1986), personal cost is the risk of retaliation from others within the institution which influences a whistleblower to report a fraud (Ponemon, 1994). The personal cost can be based on subjective assessment, meaning that the perceived or expected personal cost among employees might be different, depending on their assessment (Curtis, 2006).

This retaliation risk makes an individual sets themselves apart from the risk when doing whistleblowing. The undesired consequences of a whistleblower include loss of a job, revenge threat, and social isolation at work (Chiu, 2003). This is what makes some whistleblowers opt to repot frauds anonymously. Schultz et al. (1993) define personal cost as an employee's perception of retaliation/revenge risk or sanction from the institution members which may discourage employees from reporting it. Personal cost is one of the main reasons for one's reluctance to report suspected offense (Bagustianto \& Nurkholis, 2012). These informants believe that their reports would not be followed up, they will experience retaliation, or the management will not protect them from any retaliation threat, particularly in those types of offenses which involve their supervisors in the institution (Septianti, 2013). Retaliation may occur in intangible forms, such as imbalanced performance assessment, inhibited salary promotion, employment contract termination, or transfer to undesired positions (Curtis, 2006). In the results of other studies, it is found that the decision to be a whistleblower is considered unethical. The greater a person's perception, the less likely this person to do the whistleblowing.

The research conducted by Alleyne et al. (2017) finds that personal cost has a negative influence on internal and external whistleblowing intention. The respondents in Alleyne 
Indriani, Yulia, Nadirsyah, \& Ariska

Whistleblowing Intention, Personal Cost, Organizational Commitment and Fraud Seriousness Level

et al. (2017) study are accountants working for government institutions in Barbados. Thus it makes them afraid of being retaliation victims such as being mocked, harassed, or intimidated by the offenders and the management. Therefore, the hypothesis proposed in this research is:

\section{$\boldsymbol{H}_{1}$ : Personal cost negatively influences whistleblowing intention.}

\section{Influence of Fraud Seriousness Level on Whistleblowing Intention}

A study finds that the decision to disclose unlawful action frequently depends on the nature or type of frauds committed (Miceli \& Near, 1992). Miceli and Near (1985) argue that observers are more likely to report frauds: (1) if they have convincing evidence on the frauds; (2) if the frauds are serious; and (3) if they witness it in person. Another research has found that the more serious the issue, the more likely for whistleblowing to occur (Ayers \& Kaplan, 2005; Bagustianto \& Nurkholis, 2012; S. Husniati et al., 2017; Kaplan \& Schultz, 2007; Miceli \& Near, 1985; Near \& Miceli, 1996; Schultz et al., 1993).

Every type of fraud is something unique (Miceli et al., 2008) and any institution member may have a different reaction to these many types of frauds (Miceli et al., 1991). Whether or not an institution member will react to any form of frauds might depend on who benefits from this action. Miceli et al. (1991) add that if the fraud is done for the benefit of certain individuals, then it can trigger the institution members to respond to it. This is because the action is deemed to only benefit the culprit and it might also damage the institution's bottom line, yet if the fraud is done for the institution's benefit, then it is less likely for whistleblowing to occur (Ahmad, 2011).

Fraud seriousness level can be measured from how great the losses the institution might suffer as characterized by its materiality. Thus, an individual is more likely to report frauds of serious nature than the non-serious ones due to the individual's perceived greater losses the institution might suffer from if it is not reported (Hanif \& Odiatma, 2017). Additionally, an individual also shares a sense of responsibility to protect their workplace from any danger or loss threat (Gottshalk, 2011) as a spirit of prosocial theory. Phares and Wilson (1972) have also studied the importance of whistleblowing and fraud seriousness level. Using a scenario, Phares and Wilson find that in cases where the frauds are evident, and the attribution of responsibility raises significantly with the severity level of that action.

Furthermore, Graham (1986) find that in measuring the fraud seriousness level, an individual should objectively examine the characteristics, frequency, and how other employees in the institution can be affected by the wrongful action. Previous studies have associated fraud seriousness level and external whistleblowing. This means when the fraud is serious; then the observer will reach the institution to report the action (King, 1997; Miceli \& Near, 1984). While, the type of frauds is related to perception formation, fraud seriousness level cannot be measured from the type of frauds. The level of fraud seriousness may be varied. Several previous studies use quantitative perspective to measure fraud seriousness like Schultz et al. (1993) and Menk (2011) who 
Indriani, Yulia, Nadirsyah, \& Ariska

Whistleblowing Intention, Personal Cost, Organizational Commitment and Fraud Seriousness Level

apply the materiality concept to accounting context, leading them to measure fraud seriousness based on the amount variation of wrongdoing/fraud/loss value as a result of fraud. This quantitative perspective is the easiest approach to apply since its indicators are clear, measurable, and easily observable (Bagustianto \& Nurkholis, 2012). Setyawati et al. (2015) find that fraud seriousness level has a significant influence on Intention to do internal whistleblowing. Therefore, the hypothesis proposed in this research is as follows:

\section{$\mathrm{H}_{2}$ : Fraud seriousness level has a positive influence on whistleblowing intention.}

\section{Influence of Organizational Commitment on Whistleblowing Intention}

Organizational commitment is part of a prosocial theory. In prosocial theory, individual behavior is directed to achieve individual, group and institution's welfare (Brief \& Motowidlo, 1986). Every institution needs a commitment which will be the guidelines for its employees to do various activities in an institution (Wahyuningsih, 2016). Commitment as a condition where an individual side with the institution and their goals and to wish are to maintain their membership and support the institution in any form whatsoever (Hatmoko, 2006; Miftah, 2012; Robbins, 2007). An employee with high organizational commitment within themselves will also have a high sense of belonging to the organization, resulting in the absence of doubt to do the whistleblowing since they believe that what they do will prevent the institution from being destroyed (Husniati et al., 2017).

Some theoretical models from studies on whistleblowing have acknowledged the potential influence of organizational commitment (Dozier \& Miceli, 1985; Husniati et al., 2017; Mesmer-Magnus \& Viswesvaran, 2005; Miceli \& Near, 1988; Near \& Miceli, 1985; Street, 1995). Street (1995) argues that if an individual has a high organizational commitment, they are more likely to show prosocial behavior of whistleblowing than when the organizational commitment yang is lower. Therefore, the hypothesis proposed in this research is:

\section{$\mathrm{H}_{3}$ : Organizational commitment has a positive influence on whistleblowing intention.}

Also, this treats variable organizational commitment as an intervening variable which will see the influence of mediating variable organizational commitment between personal cost on whistleblowing intention and fraud seriousness level on whistleblowing intention. Organizational commitment is the variable with positive influence whistleblowing intention. Thus, the higher the organizational commitment, the higher the Intention of whistleblowers to report frauds or swindles. Therefore, the hypothesis proposed is:

$\boldsymbol{H}_{3 a}$ : Organizational commitment mediates the relation between personal cost and whistleblowing intention. 
Indriani, Yulia, Nadirsyah, \& Ariska

Whistleblowing Intention, Personal Cost, Organizational Commitment and Fraud Seriousness Level

$\boldsymbol{H}_{3 b}$ : Organizational commitment mediates the relation between fraud seriousness level and whistleblowing intention.

\section{Research Method}

\section{Sample and Data Collection}

The respondents of this research are civil servants or contract employees working for government institutions of Regencies/Municipalities in Aceh Province. The sample size in this research is adjusted with the research model, namely PLS-SEM (Partial Least Square-Structural Equation Modelling). According to Hair, Hult, Ringle, and Sarstedt (2014:20) the sample size if PLS-SEM is used should be greater than or equal to: a) ten (10) times the number of greatest formative indicators used to measure a single construct; b) ten (10) times the number of greatest structural paths directed to certain constructs in a structural model. The questionnaire was distributed using the web with google document via google form spread to respondents via email, WhatsApp, Line, and other social media. The distribution was made from May to July, and at the determined due date, 103 questionnaires were completed. According to Hair et al. (2014:20), PLSSEM can be used to deal with the problem of complex correlation between variables with a small data sample size (30-100).

\section{Variables Measurement}

In this research, whistleblowing is defined as disclosing illegal, immoral or unlawful practices under the control of leaders by institution members, both current or former members, to individuals or the institution which may cause remedial action effects (Near \& Miceli, 1985:4). There were 3 parts of whistleblowing questions, namely: 1 ) perception of whistleblowing using 6 question items measured in three ways, i.e., "yes", "no", or maybe; 2) the whistleblowing action consisting of 8 questions; 3 ) questions for whistleblowing intention using 5 point Likert scale, starting from $1=$ strongly disagree to $5=$ strongly agree. The questions were developed by Alleyne et al. (2017), and Nayir and Herzig (2012) and the indicators were developed by Alleyne et al. (2016).

The personal cost is the employees' perceived retaliation/revenge risks or sanctions from the institution members, which may decrease employees' interest to report (Schultz et al., 1993). The personal cost variable was measured using 4 question indicators developed by Pillay, Ramphul, Dorasamy, and Meyer (2015) using a 7-point Likert scale.

Fraud seriousness level is defined by Hanif and Odiatma (2017) as the extent of consequence related to the extent of loss (or profit) received by victims (or beneficiaries) of morally questionable behavior. This variable was assessed using 1 question indicator developed by Alleyne et al. (2017). The variable was measured using the $\mathrm{t}$-point Likert scale from $1=$ strongly disagree to 5 = strongly agree. 
The organizational commitment in this research was defined by Mowday, Steers, and Porter (1979) as a relative strength in identifying individual involvement in a certain institution. This variable was measured using positive and negative statements. There were 8 statement indicators developed by Mowday et al. (1979) to assess the organizational commitment variable. This variable was measured using a 7-point Likert scale. In this research, organizational commitment served as both an independent and intervening variable.

\section{Data Analysis Method}

The data were analyzed using PLS-SEM (Partial Least Square-Structural Equation Modelling) with WarpPLS 4.0 application. The researchers used PLS-SEM since this research had complex variables and it had direct and indirect influence tests with the organizational commitment playing the mediating role.

\section{Result and Discussion}

\section{Descriptive Statistic of Research Variable}

This research was complemented with research questions on the respondent's perception of whistleblowing and whistleblowing action. Table 1 shows the respondents' demographic profiles while the research result on perception of whistleblowing can be seen in Table 2 . The research result showed that $61 \%$ of the respondents agree that whistleblowing was part of ethics and only $46.6 \%$ of the respondents were willing to report offenses to the management, and $53.4 \%$ of them would report offenses to a trustworthy channel/line within the agency they were working and $50.5 \%$ would not report to a line beyond the organization, and even $70.9 \%$ of the respondents would not report it to media, and finally only $32 \%$ were willing to report to supervisory board.

Table 1 Presents a Summary of 103 Respondents' Demographic Profiles

\begin{tabular}{llcc}
\hline No & \multicolumn{1}{c}{ Characteristics Responden } & Frequency (N) & Percentage (\%) \\
\hline 1 & Regency/Municipality & & \\
& Banda Aceh & 16 & 15.5 \\
& Sabang & 2 & 1.9 \\
Great Aceh & 6 & 5.8 \\
Pidie & 4 & 3.9 \\
Pidie Jaya & 3 & 2.9 \\
Bireuen & 15 & 14.6 \\
Lhokseumawe & 4 & 3.9 \\
West Aceh & 7 & 6.8 \\
Aceh Jaya & 3 & 2.9 \\
Simeulue & 2 & 1.9 \\
Nagan Raya & 1 & 1 \\
Southwest Aceh & 1 & 1 \\
South Aceh & 1 & 1 \\
Aceh Singkil & 2 & 1.9 \\
Subulussalam & 0 & 0 \\
\hline
\end{tabular}


Indriani, Yulia, Nadirsyah, \& Ariska

Whistleblowing Intention, Personal Cost, Organizational Commitment and Fraud Seriousness Level

Table 1 Presents a Summary of 103 Respondents' Demographic Profiles (Continued)

\begin{tabular}{|c|c|c|c|}
\hline No & Characteristics Responden & Frequency (N) & Percentage (\%) \\
\hline \multirow[t]{10}{*}{1} & Regency/Municipality & & \\
\hline & North Aceh & 3 & 2.9 \\
\hline & Langsa & 14 & 13.6 \\
\hline & East Aceh & 2 & 1.9 \\
\hline & Aceh Tamiang & 4 & 3.9 \\
\hline & Central Aceh & 5 & 4.9 \\
\hline & Bener Meriah & 4 & 3.9 \\
\hline & Gayo Lues & 3 & 2.9 \\
\hline & Southeast Aceh & 1 & 1 \\
\hline & Total & 103 & 100 \\
\hline \multirow[t]{4}{*}{2} & Sex & & \\
\hline & 1. Male & 42 & 40.8 \\
\hline & 2. Female & 61 & 59.2 \\
\hline & 3. Total & 103 & 100 \\
\hline \multirow[t]{6}{*}{3} & Age & & \\
\hline & a. 20-30 years old & 24 & 23.3 \\
\hline & b. $30-40$ years old & 38 & 36.9 \\
\hline & c. 40-50 years old & 31 & 30.1 \\
\hline & d. $>50$ years old & 10 & 9.7 \\
\hline & e. Total & 103 & 100 \\
\hline \multirow[t]{6}{*}{4} & Religion & & \\
\hline & Islam & 103 & 100 \\
\hline & Christianity & 0 & 0 \\
\hline & Hinduism & 0 & 0 \\
\hline & Buddhism & 0 & 0 \\
\hline & Total & 103 & 100 \\
\hline \multirow[t]{7}{*}{5} & Last Education & & \\
\hline & 1. Senior High School/equal & 2 & 2 \\
\hline & 2. Diploma (D1/D2/D3) & 17 & 16.5 \\
\hline & 3. Bachelor (S1) & 53 & 51.4 \\
\hline & 4. Master (S2) & 30 & 29.1 \\
\hline & 5. Doctoral (S3) & 1 & 1 \\
\hline & 6. Total & 103 & 100 \\
\hline \multirow[t]{4}{*}{6} & Status & & \\
\hline & 1. Civil Servants & 83 & 80.6 \\
\hline & 2. Contract Employees & 20 & 19.4 \\
\hline & 3. Total & 103 & 100 \\
\hline \multirow[t]{7}{*}{7} & Work Experience & & \\
\hline & $<1$ year & 3 & 2.9 \\
\hline & $1-5$ years & 20 & 19.4 \\
\hline & $6-15$ years & 48 & 46.6 \\
\hline & $16-25$ years & 22 & 21.4 \\
\hline & $>25$ years & 10 & 9.7 \\
\hline & Total & 103 & 100 \\
\hline \multirow[t]{6}{*}{8} & Fields of Occupation & & \\
\hline & Administrative Field & 36 & 35 \\
\hline & Financial Field & 21 & 20.4 \\
\hline & Staffing Field & 9 & 8.7 \\
\hline & Others & 37 & 35.9 \\
\hline & Total & 103 & 100 \\
\hline
\end{tabular}


Table 1 Presents a Summary of 103 Respondents' Demographic Profiles (Continued)

\begin{tabular}{clcc}
\hline No & \multicolumn{1}{c}{ Characteristics Responden } & Frequency (N) & Percentage (\%) \\
\hline 9 & Position & 2 & 1.9 \\
& Secretary & 1 & 1 \\
& Agency Head & 1 & 1 \\
& Bureau Head & 2 & 1.9 \\
Division Head & 4 & 3.9 \\
Board Head & 4 & 3.9 \\
Sub-division Head & 1 & 1 \\
Sub-board Head & 4 & 3.9 \\
Section Head & 2 & 1.9 \\
Administrative Head & 1 & 1 \\
Room Head & 51 & 49.5 \\
Staff & 30 & 29.1 \\
Others & 103 & 100 \\
Total & & \\
\hline
\end{tabular}

The results of this research indicated that respondents felt safer to report the offense internally than to external parties or media. This was the same as Carson, Verdo, and Wokutch (2008) and Park and Blenkinsopp (2009) who found that external whistleblowing was more dangerous than internal whistleblowing for it could lead to retaliation and serious damage to the institution.

Table 2 Respondent's Response to Whistleblowing Perception

\begin{tabular}{|c|c|c|c|c|}
\hline \multirow{2}{*}{ No } & \multirow{2}{*}{ Question } & \multicolumn{3}{|c|}{ Answer Score } \\
\hline & & Yes & No & Maybe \\
\hline 1 & Do you see whistleblowing as an ethic? & $\begin{array}{c}63 \\
612 \%\end{array}$ & $\begin{array}{c}18 \\
17 \%\end{array}$ & $\begin{array}{c}22 \\
214 \%\end{array}$ \\
\hline 2 & $\begin{array}{l}\text { Will you prefer to report offenses to the } \\
\text { management within the institution you } \\
\text { are working for? }\end{array}$ & $\begin{array}{c}48 \\
46.6 \%\end{array}$ & $\begin{array}{c}24 \\
23.3 \%\end{array}$ & $\begin{array}{c}31 \\
30.1 \%\end{array}$ \\
\hline 3 & $\begin{array}{l}\text { Will you prefer to report offenses to a } \\
\text { trustworthy channel/line within the } \\
\text { institution you are currently working for? }\end{array}$ & $\begin{array}{c}55 \\
53.4 \%\end{array}$ & $\begin{array}{c}26 \\
25.2 \%\end{array}$ & $\begin{array}{c}22 \\
21.4 \%\end{array}$ \\
\hline 4 & $\begin{array}{l}\text { Will you prefer to report offenses to a } \\
\text { trustworthy channel/line beyond the } \\
\text { institution you are currently working for? }\end{array}$ & $\begin{array}{c}25 \\
24.3 \%\end{array}$ & $\begin{array}{c}52 \\
50.5 \%\end{array}$ & $\begin{array}{c}26 \\
25.2 \%\end{array}$ \\
\hline 5 & $\begin{array}{l}\text { Will you prefer to report offenses to the } \\
\text { media? }\end{array}$ & $\begin{array}{l}5 \\
4.9 \%\end{array}$ & $\begin{array}{c}73 \\
70.9 \%\end{array}$ & $\begin{array}{c}25 \\
24.3 \%\end{array}$ \\
\hline 6 & $\begin{array}{l}\text { Will you prefer to report to the } \\
\text { supervisory board? }\end{array}$ & $\begin{array}{c}33 \\
32 \%\end{array}$ & $\begin{array}{c}37 \\
35.9 \% \\
\end{array}$ & $\begin{array}{c}33 \\
32 \%\end{array}$ \\
\hline
\end{tabular}

This research also explores the respondent's response to whistleblowing action which can be seen in Table 3. It can be seen that $41(39.8 \%)$ respondents had noticed or seen offenses within the institution. Out of these 41 respondents who noticed offenses, $12.2 \%$ did the whistleblowing action by directly talking to the offenders, $26.8 \%$ told the higher management, $7.3 \%$ reported to the authority beyond the institution, $22 \%$ did nothing, and the whistleblowing action most commonly done was informing about it to the trustworthy channel/line in the institution at $31.7 \%$. 
Table 3 Respondent's Response to Whistleblowing Action

\begin{tabular}{clcc}
\hline No & Factor & Frequency (N) & Percent (\%) \\
\hline 1 & Aware of/noticing fraud & 41 & \\
Yes & 62 & 39.8 \\
No & $\mathbf{1 0 3}$ & $\mathbf{1 0 0}$ \\
& & \\
Total & & 12,2 \\
Whistleblowing Action & 5 & 26,8 \\
Directly talking to the offender & 11 & 31,7 \\
Informing the higher management & 13 & 0 \\
Informing to trustworthy channel/line in the institution & 0 & 0 \\
Writing an incident report & 0 & 7,3 \\
Informing the media/external agency & 3 & 22 \\
Reporting to the authority beyond the institution & 9 & $\mathbf{1 0 0}$ \\
Doing nothing & $\mathbf{4 1}$ & \\
Total & & \\
\hline
\end{tabular}

The respondents' response to whistleblowing intention can be seen in Table 4 . The results for the personal cost variable can be seen in Table 5. The mean score of the respondents was 5.571. This showed that the respondent's perception of retaliation was high, yet among the questions on personal cost, the statement with the highest mean score was whistleblower's reluctance to be covered by media, i.e., at 5.641 .

Table 4 Respondent's Response to Whistleblowing Intention

\begin{tabular}{|c|c|c|c|c|c|c|c|}
\hline \multirow{2}{*}{ No } & \multirow{2}{*}{ Statement } & \multicolumn{5}{|c|}{ Answer Score } & \multirow{2}{*}{ Mean } \\
\hline & & SD & D & $\mathbf{N}$ & A & SA & \\
\hline 1 & $\begin{array}{l}\text { I will report it using a } \\
\text { pseudonym. }\end{array}$ & $\begin{array}{c}10 \\
9.7 \%\end{array}$ & $\begin{array}{c}18 \\
17.5 \%\end{array}$ & $\begin{array}{c}33 \\
32 \%\end{array}$ & $\begin{array}{c}28 \\
27.2 \%\end{array}$ & $\begin{array}{c}14 \\
13.6 \%\end{array}$ & 3.17 \\
\hline 2 & $\begin{array}{l}\text { I will report offenses, but I will } \\
\text { not give any information about } \\
\text { myself. }\end{array}$ & $\begin{array}{c}4 \\
3.9 \%\end{array}$ & $\begin{array}{c}22 \\
21.4 \%\end{array}$ & $\begin{array}{c}34 \\
33 \%\end{array}$ & $\begin{array}{c}28 \\
27.2 \%\end{array}$ & $\begin{array}{c}15 \\
14.6 \%\end{array}$ & 3.27 \\
\hline 3 & $\begin{array}{l}\text { I will report offenses to the } \\
\text { authority beyond the } \\
\text { institution I am working for. }\end{array}$ & $\begin{array}{c}18 \\
17.5 \%\end{array}$ & $\begin{array}{c}34 \\
33 \%\end{array}$ & $\begin{array}{c}29 \\
28.2 \%\end{array}$ & $\begin{array}{c}13 \\
12.6 \%\end{array}$ & $\begin{array}{c}9 \\
8.7 \%\end{array}$ & 2.62 \\
\hline 4 & $\begin{array}{l}\text { I will give information to } \\
\text { external parties. }\end{array}$ & $\begin{array}{c}25 \\
24.3 \%\end{array}$ & $\begin{array}{c}39 \\
37.9 \%\end{array}$ & $\begin{array}{c}25 \\
24.3 \%\end{array}$ & $\begin{array}{l}8 \\
7.8 \%\end{array}$ & $\begin{array}{c}6 \\
5.8 \%\end{array}$ & 2.33 \\
\hline 5 & I will tell the public about it. & $\begin{array}{c}26 \\
25.2 \%\end{array}$ & $\begin{array}{c}42 \\
40.8 \%\end{array}$ & $\begin{array}{c}20 \\
19.4 \%\end{array}$ & $\begin{array}{c}8 \\
7.8 \%\end{array}$ & $\begin{array}{c}7 \\
6.8 \%\end{array}$ & 2.30 \\
\hline 6 & $\begin{array}{l}\text { I will report to the right person } \\
\text { within the institution. }\end{array}$ & $\begin{array}{c}2 \\
1.9 \%\end{array}$ & $\begin{array}{c}13 \\
12.6 \%\end{array}$ & $\begin{array}{c}26 \\
25.2 \%\end{array}$ & $\begin{array}{c}37 \\
35.9 \%\end{array}$ & $\begin{array}{c}25 \\
24.3 \%\end{array}$ & 3.68 \\
\hline 7 & $\begin{array}{l}\text { I will use a reporting } \\
\text { line/channel within the } \\
\text { institution. }\end{array}$ & $\begin{array}{l}3 \\
2.9 \%\end{array}$ & $\begin{array}{c}16 \\
15.5 \%\end{array}$ & $\begin{array}{c}26 \\
25.2 \%\end{array}$ & $\begin{array}{c}39 \\
37.9 \%\end{array}$ & $\begin{array}{c}19 \\
18.4 \%\end{array}$ & 3.53 \\
\hline 8 & $\begin{array}{l}\text { I will tell the internal supervisor } \\
\text { about it. }\end{array}$ & $\begin{array}{c}3 \\
2.9 \%\end{array}$ & $\begin{array}{c}18 \\
17.5 \%\end{array}$ & $\begin{array}{c}34 \\
33 \%\end{array}$ & $\begin{array}{c}33 \\
32 \%\end{array}$ & $\begin{array}{c}15 \\
14.6 \%\end{array}$ & 3.28 \\
\hline & & & & & & Average & 3.02 \\
\hline
\end{tabular}

Note: $\mathrm{SD}=$ Strongly Disagree; $\mathrm{D}=$ disagree; $\mathrm{N}=$ Neutral; $\mathrm{A}=\mathrm{Agree}$; $\mathrm{SA}=$ Strongly Agree 
Indriani, Yulia, Nadirsyah, \& Ariska

Whistleblowing Intention, Personal Cost, Organizational Commitment and Fraud Seriousness Level

Table 5 Respondent's Response to Personal Cost and Organizational Commitment Variables

\begin{tabular}{|c|c|c|c|c|c|c|c|c|c|}
\hline \multirow{2}{*}{ No } & \multirow{2}{*}{ Statement } & \multicolumn{7}{|c|}{ Answer Score } & \multirow{2}{*}{ Mean } \\
\hline & & SD & D & LD & $\mathbf{N}$ & LA & A & SA & \\
\hline \multicolumn{10}{|c|}{ Personal cost } \\
\hline \multirow[t]{2}{*}{1} & I will not be a & 0 & 0 & 0 & 17 & 38 & 26 & 22 & 5.515 \\
\hline & $\begin{array}{l}\text { whistleblower because } \\
\text { the leader's power is very } \\
\text { high and rigid. }\end{array}$ & $0 \%$ & $0 \%$ & $0 \%$ & $16.5 \%$ & $36.9 \%$ & $25.2 \%$ & $21.4 \%$ & \\
\hline \multirow[t]{2}{*}{2} & I do not want to be a & 0 & 0 & 0 & 20 & 28 & 38 & 17 & 5.505 \\
\hline & $\begin{array}{l}\text { whistleblower because } \\
\text { my institution will make a } \\
\text { retaliation to me. }\end{array}$ & $0 \%$ & $0 \%$ & $0 \%$ & $19.4 \%$ & $27.2 \%$ & $36.9 \%$ & $16.5 \%$ & \\
\hline \multirow[t]{2}{*}{3} & I do not want to be a & 0 & 0 & 0 & 11 & 37 & 35 & 20 & 5.621 \\
\hline & $\begin{array}{l}\text { whistleblower because } \\
\text { the people involved in } \\
\text { illegal, immoral, or } \\
\text { prohibited practices in my } \\
\text { institution might } \\
\text { retaliate. }\end{array}$ & $0 \%$ & $0 \%$ & $0 \%$ & $10.7 \%$ & $35.9 \%$ & $34 \%$ & $19.4 \%$ & \\
\hline \multirow[t]{3}{*}{4} & I do not want to be a & 0 & 0 & 0 & 15 & 28 & 39 & 21 & 5.641 \\
\hline & $\begin{array}{l}\text { whistleblower if I am to } \\
\text { be covered by the media. }\end{array}$ & $0 \%$ & $0 \%$ & $0 \%$ & $14.6 \%$ & $27.2 \%$ & $37.9 \%$ & $20.4 \%$ & \\
\hline & & & & & & & & Average & 5.571 \\
\hline \multicolumn{2}{|c|}{ Organizational Commitment } & SD & D & LD & $\mathbf{N}$ & LA & A & SA & \\
\hline \multirow[t]{2}{*}{1} & Trying and working & 6 & 2 & 2 & 10 & 10 & 29 & 44 & 5.709 \\
\hline & $\begin{array}{l}\text { harder to help the } \\
\text { institution achieve its } \\
\text { goals. }\end{array}$ & $5.8 \%$ & $1.9 \%$ & $1.9 \%$ & $9.7 \%$ & $9.7 \%$ & $28.2 \%$ & $42.7 \%$ & \\
\hline \multirow[t]{2}{*}{2} & Telling friends that the & 3 & 2 & 5 & 17 & 17 & 31 & 28 & 5.408 \\
\hline & $\begin{array}{l}\text { institution I am working } \\
\text { for is a good organization. }\end{array}$ & $2.9 \%$ & $1.9 \%$ & $4.9 \%$ & $16.5 \%$ & $16.5 \%$ & $30.1 \%$ & $27.2 \%$ & \\
\hline \multirow[t]{2}{*}{3} & Willing to accept any kind & 1 & 7 & 8 & 11 & 30 & 34 & 12 & 5.058 \\
\hline & $\begin{array}{l}\text { of assignment to continue } \\
\text { to work for the } \\
\text { institution. }\end{array}$ & $1 \%$ & $6.8 \%$ & $7.8 \%$ & $10.7 \%$ & $29.1 \%$ & $33 \%$ & $11.7 \%$ & \\
\hline \multirow[t]{2}{*}{4} & The values applied to the & 1 & 7 & 7 & 14 & 32 & 30 & 12 & 5.010 \\
\hline & $\begin{array}{l}\text { institution share some } \\
\text { similarities with the } \\
\text { values I follow. }\end{array}$ & $1 \%$ & $6.8 \%$ & $6.8 \%$ & $13.6 \%$ & $31.1 \%$ & $29.2 \%$ & $11.7 \%$ & \\
\hline \multirow[t]{2}{*}{5} & Proud to tell others since & 6 & 12 & 8 & 22 & 23 & 18 & 14 & 4.495 \\
\hline & $\begin{array}{l}\text { ( } \mathrm{am}) \text { part of the } \\
\text { institution. }\end{array}$ & $5.8 \%$ & $11.7 \%$ & $7.8 \%$ & $21.4 \%$ & $22.3 \%$ & $17.5 \%$ & $13.6 \%$ & \\
\hline \multirow[t]{2}{*}{6} & The institution I am & 2 & 8 & 3 & 11 & 19 & 40 & 20 & 5.301 \\
\hline & $\begin{array}{l}\text { working for inspires me } \\
\text { to improve my } \\
\text { performance. }\end{array}$ & $1.9 \%$ & $7.8 \%$ & $2.9 \%$ & $10.7 \%$ & $18.4 \%$ & $38.8 \%$ & $19.4 \%$ & \\
\hline \multirow[t]{2}{*}{7} & Frequently find it hard to & 8 & 6 & 2 & 12 & 7 & 39 & 29 & 5.301 \\
\hline & $\begin{array}{l}\text { agree with the } \\
\text { institution's policy on } \\
\text { important matters } \\
\text { related to its employees. }\end{array}$ & $7.8 \%$ & $5.8 \%$ & $1.9 \%$ & $11.7 \%$ & $6.8 \%$ & $37.9 \%$ & $28.2 \%$ & \\
\hline \multirow[t]{2}{*}{8} & The institution I am & 1 & 7 & 7 & 16 & 28 & 32 & 12 & 5.010 \\
\hline & $\begin{array}{l}\text { working for is the best } \\
\text { compared to other } \\
\text { institutions. }\end{array}$ & $1 \%$ & $6.8 \%$ & $6.8 \%$ & $15.5 \%$ & $27.2 \%$ & $31.1 \%$ & $11.7 \%$ & \\
\hline & & & & & & & & Mean & 5.162 \\
\hline
\end{tabular}

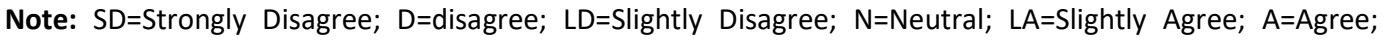
SA=Strongly Agree

Based on Table 5, the mean score of the respondent's response to organizational commitment was 5.162 , indicating that respondents slightly agreed with organizational 
Indriani, Yulia, Nadirsyah, \& Ariska

Whistleblowing Intention, Personal Cost, Organizational Commitment and Fraud Seriousness Level

commitment. The statement with the greatest mean was trying and working harder to help the institution achieve its goals at 5.079. On the contrary, the statement proud to tell others that $(\mathrm{I} \mathrm{am})$ part of the institution was the one with the least mean score at 4.495. The fraud seriousness level at Government Institutions of Regencies/ Municipalities in Aceh Province was moderate, i.e., it was not too high yet not too low either. This was shown by the mean score of the respondent's response to fraud seriousness level variable at 2.91 on Table 6.

Table 6 Respondent's Response to Variable Fraud Seriousness Level

\begin{tabular}{|c|c|c|c|c|c|c|c|}
\hline \multirow{2}{*}{ No } & \multirow{2}{*}{ Statement } & \multicolumn{5}{|c|}{ Answer Score } & \multirow{2}{*}{ Mean } \\
\hline & & VL & $\mathbf{L}$ & $\mathbf{N}$ & H & VH & \\
\hline 1 & $\begin{array}{l}\text { Score the seriousness level of } \\
\text { frauds occurring in the } \\
\text { institution you are working for. }\end{array}$ & $\begin{array}{c}8 \\
7.8 \%\end{array}$ & $\begin{array}{c}31 \\
30.1 \%\end{array}$ & $\begin{array}{c}34 \\
33 \%\end{array}$ & $\begin{array}{c}22 \\
21.4 \%\end{array}$ & $\begin{array}{c}8 \\
7.8 \%\end{array}$ & 2.91 \\
\hline
\end{tabular}

Note: VL=Very Low; L=Low; $\mathrm{N}=$ Neutral; $\mathrm{H}=\mathrm{High}$; $\mathrm{VH}=$ Very High

\section{Results of Hypothesis Testing}

Results of Outer Model Test

The outer model test was conducted to assess the reliability and validity of indicators which form the latent variable. According to Hair, Black, Babin, and Anderson (2010) the loading factor which qualifies the criteria is above 0.70, and Ghozali and Latan (2014) suggest that for social research the loading factor value over 0.50 is acceptable. If an indicator is below 0.50, then these indicators are eliminated for processing. The resulting loading factors for whistleblowing intention, personal cost, organizational commitment, and fraud seriousness level upon eliminating the loading factor below 0.50 can be seen in Table 7 .

According to Table 7, we can see the values of loading factor, CR (Composite Reliability), AVE (Average Variance Extracted), and square root AVE (VAVE). The result of reliability test showed a good result for whistleblowing intention, personal cost, organizational commitment, and fraud seriousness level since the $C R$ values of each variable were 0.843 (IW), 0.853 (PC), 0.922 (KO), dan 1.000 (KK) which were greater than 0.70 . The instrument's internal consistency level was also high, as could be seen from Cronbach's Alpha $\geq 0.50$. The validity test for each variable also showed a good result as could be seen from the AVE value which was greater than $>0.50$ and VAVE of each variable was greater than AVE value.

Result of Inner Model Test

The inner model test was used to determine whether the research hypotheses were confirmed or rejected. The summary of its result can be seen in Table 8 . In Table 8, it was shown that personal cost had path coefficients of -0.250 and $p$-value $=0.030$, meaning it was less than 0.05 . Thus $\mathrm{H}_{1}$ was confirmed. Therefore it could be concluded that the personal cost variable has a direct negative influence on whistleblowing intention. In other words, the higher the personal cost, the lower the whistleblowing 
intention would be. This result indicated that respondents had no interest to be a whistleblower for they were afraid of possible retaliation if they reported something improper occurring at work.

Table 7 Result of Outer Model Test

\begin{tabular}{|c|c|c|c|c|c|c|}
\hline Variable & Indicator & $\begin{array}{l}\text { Loading } \\
\text { Factor } \\
\geq 0.50\end{array}$ & $\begin{array}{c}C R \\
\geq 0.70\end{array}$ & $\begin{array}{c}\text { AVE } \\
>50 \%\end{array}$ & VAVE & $\begin{array}{l}\text { Cron- } \\
\text { bach's } \\
\text { alpha }\end{array}$ \\
\hline \multirow{5}{*}{$\begin{array}{l}\text { Whistleblowing } \\
\text { Intention }\end{array}$} & IW1 & 0.739 & \multirow[t]{5}{*}{0.843} & \multirow[t]{5}{*}{0.520} & \multirow[t]{5}{*}{0.721} & \multirow[t]{5}{*}{0.78} \\
\hline & IW2 & 0.743 & & & & \\
\hline & IW3 & 0.801 & & & & \\
\hline & IW4 & 0.619 & & & & \\
\hline & IW5 & 0.689 & & & & \\
\hline \multirow[t]{4}{*}{ Personal cost } & P1 & 0.770 & \multirow[t]{4}{*}{0.853} & \multirow[t]{4}{*}{0.595} & \multirow[t]{4}{*}{0.771} & \multirow[t]{4}{*}{0.77} \\
\hline & P2 & 0.848 & & & & \\
\hline & P3 & 0.819 & & & & \\
\hline & P4 & 0.630 & & & & \\
\hline \multirow{7}{*}{$\begin{array}{l}\text { Organizational } \\
\text { commitment }\end{array}$} & KO1 & 0.561 & \multirow[t]{7}{*}{0.922} & \multirow[t]{7}{*}{0.636} & \multirow[t]{7}{*}{0.798} & \multirow[t]{7}{*}{0.90} \\
\hline & $\mathrm{KO} 2$ & 0.648 & & & & \\
\hline & KO3 & 0.920 & & & & \\
\hline & KO4 & 0.929 & & & & \\
\hline & KO6 & 0.645 & & & & \\
\hline & KO7 & 0.918 & & & & \\
\hline & KO8 & 0.868 & & & & \\
\hline $\begin{array}{l}\text { Fraud seriousness } \\
\text { level }\end{array}$ & KK1 & 1.000 & 1.000 & 1.000 & 1.000 & 0.99 \\
\hline
\end{tabular}

This research supported Alleyne et al. (2017); Lestari and Yaya (2017); and Setyawati et al. (2015) who explained that whistleblower was concerned that they might be subjected to retaliation from the offender or the management. This action had no serious effect on the whistleblower, as well as on the management procedure and the organization, thus the whistleblower needed support and self-confidence in the internal reporting process, yet this research was inconsistent with Bagustianto and Nurkholis (2012) who found that personal cost influenced whistleblowing intention.

Table 8 Results of Hypothesis Testing

\begin{tabular}{lcccc} 
& Hypothesis & Coefficient & p value & Conclusion \\
\hline Direct Relation & & & & \\
PC-IW & $\mathrm{H}_{1}$ & $-0,25$ & 0.03 & Confirmed \\
KK-IW & $\mathrm{H}_{2}$ & 0.27 & 0.01 & Confirmed \\
KO-IW & $\mathrm{H}_{3}$ & 0.05 & 0.33 & Rejected \\
PC-KO (unhypothesized) & - & 0.10 & 0.28 & Rejected \\
KK-KO (unhypothesized) & - & 0.11 & 0.17 & Rejected \\
Indirect relations & & & & \\
PC-KO-IW & $\mathrm{H}_{3 a}$ & 0.005 & 0.411 & Rejected \\
KK-KO-IW & $\mathrm{H}_{3 b}$ & 0.006 & 0.336 & Rejected \\
$\mathrm{R}^{2}=0.127$ IW & & & & \\
$\mathrm{R}^{2}=0.024 \mathrm{KO}$ & & & & \\
\hline
\end{tabular}


Indriani, Yulia, Nadirsyah, \& Ariska

Whistleblowing Intention, Personal Cost, Organizational Commitment and Fraud Seriousness Level

Fraud seriousness level had a path coefficient of 0.27 and $p$-value $=0.009$. Thus $\mathrm{H}_{2}$ was confirmed. This means fraud seriousness level has a direct positive influence on whistleblowing intention at a regression coefficient of 0.265 and significant at 0.009 . This result indicated that respondents would only report fraud at a certain seriousness or materiality level. The organization members within them had no awareness yet that a public organization, particularly government organization, even the slightest fraud would lead to great losses. Thus one intended to report it if the fraud was serious. This result confirmed Setyawati et al. (2015), yet this result contradicted Hanif and Odiatma (2017) who investigated police members at Pekan Baru municipality.

The organizational commitment had a path coefficient of 0.05 and $p$-value $=0.331$. Thus $\mathrm{H}_{3}$ was rejected. This means organizational commitment did does not influence whistleblowing intention. This result rejected Street (1995) who suggested that if a person had a high organizational commitment, their prosocial value would increase and, hence, it was more likely for them to disclose something improper at work since they had the sense of responsibility of what happened. This result was not different from Lestari and Yaya (2017) and Setyawati et al. (2015).

This result also showed that organizational commitment had no mediating effect on the relationship between personal cost and whistleblowing intention as could be seen from the coefficient value at 0.054 with $p$-value $=0.411$. The organizational commitment had no mediating effect either on the relation between fraud seriousness level and whistleblowing intention as could be seen from the coefficient value of 0.331 with $p$ value $=0.366$. Therefore, it could be concluded that the organizational commitment variable could not influence the relationships among personal cost, fraud seriousness level, and whistleblowing intention.

The value of $R^{2}$ was 0.127 in whistleblowing intention variable, meaning $12.7 \%$ of changes in the whistleblowing intention variable could be explained by the changes in the personal cost, organizational commitment, and fraud seriousness level variables, and the remaining $89.9 \%$ was explained by other variables beyond the model. The value of $R^{2}$ was 0.024 in organizational commitment variable. This means $0.4 \%$ of changes in the organizational commitment variable could be explained in the changes in personal cost and fraud seriousness level variables, with the remaining $99.6 \%$ being explained by other variables beyond the model. Furthermore, $Q^{2}$ of whistleblowing intention and organizational commitment variables showed respective values of 0.143 and 0.037 . Hence, it could be concluded that the model had a predictive relevance.

\section{Goodness of Fit}

The result of the goodness of fit test of the overall model can be seen in Table 9. It can be seen that the model had fairly good fit. This was shown by the p-value of APC (Average Path Coefficient) $=0.004$ and APC, ARS (Average R-Square), and AARS (Average Adjusted R-Square) values respectively at $0.156,0.075$, and 0.052 . Moreover, the resulting AVIF (Average block VIF) and AFVIF (Average Adjusted R-Square) values $<3.3$, 
Indriani, Yulia, Nadirsyah, \& Ariska

Whistleblowing Intention, Personal Cost, Organizational Commitment and Fraud Seriousness Level

meaning that no multicollinearity was found between indicators and between exogenous (independent) variables.

Table 9 Model Goodness of Fit Test

\begin{tabular}{|c|c|c|c|}
\hline Indicator & $\begin{array}{c}\text { The goodness of Fit Level } \\
\text { Target }\end{array}$ & Estimation Result & $\begin{array}{c}\text { Goodness of Fit } \\
\text { Level }\end{array}$ \\
\hline APC & $\begin{array}{c}>0.05 \\
p \leq 0.05\end{array}$ & $\begin{array}{c}A P C=0.156 \\
p=0.004\end{array}$ & Good Fit \\
\hline ARS & $>0.05$ & 0.075 & Good Fit \\
\hline AARS & $>0.05$ & 0.052 & Good Fit \\
\hline AVIF & $\begin{array}{c}\text { Ideally } \leq 0.03, \text { yet } \leq 5 \text { is still } \\
\text { acceptable }\end{array}$ & 1.013 & Good Fit \\
\hline AFVIF & $\begin{array}{c}\text { Ideally } \leq 0.03, \text { yet } \leq 5 \text { is still } \\
\text { acceptable }\end{array}$ & 1.089 & Good Fit \\
\hline GoF & $\begin{array}{c}\geq 0.10(\text { small }) \\
\geq 0.25(\text { medium }) \\
\geq 0.36(\text { big })\end{array}$ & 0.228 & Small \\
\hline SPR & $\begin{array}{c}\text { Ideally }=1 \text {, yet } \geq 0.7 \text { is still } \\
\text { acceptable }\end{array}$ & 1.000 & Good Fit \\
\hline $\mathrm{RSCR}$ & $\begin{array}{c}\text { Ideally }=1 \text {, yet } \geq 0.7 \text { is still } \\
\text { acceptable }\end{array}$ & 1.000 & Good Fit \\
\hline SSR & Should be $\geq 0.7$ & 1.000 & Good Fit \\
\hline NLBCDR & Should be $\geq 0.7$ & 0.500 & Not too good \\
\hline
\end{tabular}

The result of GoF was 0.228 , meaning that the model was relatively small. SPR (Symson's Paradox), RSCR (R-square Contribution Ratio), and SSR (Statistical Suppression Ratio) generated the same value, i.e., 1 . This means no causality problem was found in the model. On the contrary, NLBCDR (Nonlinear Bivariate Causality Direction Ratio) value was 0.5 or $<0.7$, meaning that it was not too good, yet this not-too-good NLBCDR in this research which was intended for hypothesis testing purpose had no influence since NLBCDR index was currently recommended for experimental research (Ghozali \& Latan, 2014).

\section{Conclusion}

The research results indicated that personal cost had a negative influence on Intention to do the whistleblowing. This means that the higher the personal cost, the lower the whistleblowing intention would be. On the contrary, the lower the personal cost, the higher the whistleblowing intention would be. This research showed that respondents were discouraged from being a whistleblower since they were afraid of the retaliation they might receive, even though respondents were aware that fraud happened at their workplace.

The research results also indicated that fraud seriousness level had a significant positive influence on the Intention to do whistleblowing, meaning that the higher the fraud seriousness level, the higher the whistleblowing intention or, the lower the fraud seriousness level, the lower the whistleblowing intention would be. This research failed 
Indriani, Yulia, Nadirsyah, \& Ariska

Whistleblowing Intention, Personal Cost, Organizational Commitment and Fraud Seriousness Level

to prove that commitment had some influence on whistleblowing intention, and that organizational commitment was expected to play a mediating role in this research. Therefore, the prosocial theory used in this research could only support the influence of personal cost and whistleblowing intention and fraud seriousness level on whistleblowing intention, yet it failed to explain the influence of organizational commitment on whistleblowing intention.

As its implication, the research results could be taken into consideration to make policies on the importance of building whistleblowing in an organization and as the basis for an organization to make a policy which can mitigate personal cost, preventing personal cost from being the reason for an individual's reluctance to be a whistleblower. The research results can also be used as a reference for accounting researchers in determining the factors influencing whistleblowing intention for future research.

This research has its limitations, including its use of a questionnaire which may cause problems if the respondent's answer is different from the real state of affairs. It can even be worse if the questionnaire is completed not by the respondents needed in this research. Such a situation is beyond the control and power of the researchers. Another limitation of this research is that it is conducted in Aceh Province. Thus its generalizability might be too low for other regions in Indonesia. As has commonly been known, Indonesia has 34 provinces with highly diverse cultures one another, and it is possible for this diversity to influence the psychological aspects of the respondents in viewing something.

It is suggested for further research also to observe other variables which may influence whistleblowing intention, particularly those which can influence the relation between personal cost and whistleblowing intention. It is expected that these variables would lessen the whistleblowers' fear of retaliation they might receive. These variables can be organizational support and quality of the system as a channel the whistleblower can use. Additionally, these variables are expected to influence the relation between fraud seriousness level and whistleblowing intention in such a way that no matter how trivial the fraud is occurring in the organization it will still be reported if the organizational support and system quality are adequate.

\section{References}

Ahmad, A. S., Smith, M., \& Ismail, Z. (2013). Internal Whistleblowing Intentions by Internal Auditors: A Prosocial Behaviour Perspective. Malaysian Accounting Review, 12(1), 145181. Retrieved from https://ari.uitm.edu.my/main/images/MAR/vol12-1/chap8.pdf

Ahmad, S. (2012). Internal Whistle-Blowing Intentions : A Study of Demographic and Individual Factors Internal Whistleblowing Intentions : A Study of Demographic and Individual Factors, 8, 1632-1645. Retrieved from http: $/ /$ ro.ecu.edu.au $/$ cgi/ viewcontent.cgi? article $=1638 \&$ context $=$ ecuworks 2012

Ahmad, S. A., Yunos, R. M., Ahmad, R. A. R., \& Sanusi, Z. M. (2014). Whistleblowing Behaviour: The Influence of Ethical Climates Theory. Procedia - Social and Behavioral Sciences, 164, 445-450. https://doi.org/10.1016/j.sbspro.2014.11.101 
Ahmad, S. A. (2011). Internal Auditor and Internal Whistleblowing Intentions: A Study of Organisational, Individual, Situational and Demographic Factors. Working Paper, Edith Cowan University.

Alam, M. D. (2014). Persepsi Aparatur Pemerintahan dan Anggota Dewan Perwakilan Rakyat Daerah Kota Malang terhadap Fraud dan Peran Whistleblowing sebagai Upaya Pencegahan dan Pendeteksian Fraud. Jurnal Ilmiah Mahasiswa FEB Universitas Brawijaya, 2(2).

Aliyah, S. (2015). Analisis Faktor-faktor yang Mempengaruhi Minat Pegawai Melakukan Tindakan Whistleblowing. Jurnal Dinamika Ekonomi \& Bisnis, 12(2), 173-189. Retrieved from https://ejournal.unisnu.ac.id/JDEB/article/viewFile/370/704

Alleyne, P., Charles-Soverall, W., Broome, T., \& Pierce, A. (2017). Perceptions, Predictors and Consequences of Whistleblowing among Accounting Employees in Barbados. Meditari Accountancy Research, 25(2), 241-267. https://doi.org/10.1108/medar-09-2016$\underline{0080}$

Alleyne, P., Hudaib, M., \& Haniffa, R. (2015). The Moderating Role of Perceived Organisational Support in Breaking the Silence of Public Accountants. Joumal of Business Ethics, 147(3), 509-527. https://doi.org/10.1108/medar-09-2016-0080

Alleyne, P., Hudaib, M., \& Pike, R. (2013). Towards a conceptual model of whistle-blowing intentions among external auditors. British Accounting Review, 45(1), 10-23. https://doi.org/10.1016/j.bar.2012.12.003

Ayers, S., \& Kaplan, S. E. (2005). Wrongdoing by Consultants : An Examination of Employees ’ Reporting Intentions. Journal of Business Etbics, 57, 121-137. https://doi.org/10.1007/s10551-004-4600-0

Bagustianto, R., \& Nurkholis. (2012). Faktor-faktor yang Mempengaruhi MInat Pegawai Negeri Sipil (PNS) untuk Melakukan Tindakan Wistleblowing (Studi pada PNS BPK RI). EKUITAS (Jurnal Ekonomi Dan Keuangan), 19(2), 276-295. https://doi.org/10.24034/i25485024.y2015.v19.i2.1769

Brennan, N., \& Kelly, J. (2007). A Study of Whistleblowing Among Trainee Auditors. The British Accounting Review, 39(1), 61-87. https://doi.org/10.1016/i.bar.2006.12.002

Brief, P., \& Motowidlo, S. J. (1986). Prosocial Organizational Behaviors. The Academy of Management Review, 11(4), 710-725. https://doi.org/10.5465/amr.1986.4283909

Campbell, D. T. (1979). Comments on The Sociobiology of Ethnics and Moralizing. Behavioral Science, 24, 37-45. https://doi.org/10.1002/bs.3830240106

Carson, T. L., Verdo, M. E., \& Wokutch, R. E. (2008). Whistleblowing for Profit: An Ethical Analysis of The Federal False Claims Act. Journal of Business Ethics, 77(3), 361-376. https://doi.org/10.1007/s10551-007-9355-y

Cassematis, P. G., \& Wortley, R. (2013). Prediction of Whistleblowing or Non-reporting Observation: The Role of Personal and Situational Factors. Journal of Business Ethics, 117(3), 615-634. https://doi.org/10.1007/s10551-012-1548-3

Chiu, R. K. (2003). Ethical Judgment and Whistleblowing Intention: Examining the Moderating Role of Locus of Control. Journal of Business Ethics, 43(1/2), 65-74. https://doi.org/10.1023/a:1022911215204

Curtis, M. B. (2006). Are Audit-related Ethical Decisions Dependent upon Mood? Journal of Business Ethics, 68(2), 191-209. https://doi.org/10.1007/s10551-006-9066-9

Dozier, J. B., \& Miceli, M. P. (1985). Potential Predictors of Whistle-Blowing: A Prosocial Behavior Perspective. The Academy of Management Review, 10(4), 823-836. https://doi.org/10.5465/amr.1985.4279105

Dyck, A., Morse, A., \& Zingales, L. (2010). Who Blows the Whistle on Corporate Fraud? The Journal of Finance, 65(6), 2213-2253. https://doi.org/10.1111/j.15406261.2010.01614.x 
Indriani, Yulia, Nadirsyah, \& Ariska

Whistleblowing Intention, Personal Cost, Organizational Commitment and Fraud Seriousness Level

Ghozali, I., \& Latan, H. (2014). Partial Least Squares: Konsep, Metode, dan Aplikasi Menggunakan Program WarpPLS 4.0 (Second). Semarang: Badan Penerbit Universitas Diponegoro.

Gottshalk, P. (2011). Pencegahan Kejahatan Kerah Putih: Peran Akuntansi. Journal of Forensic \& Investigate Accounting, 3(1).

Graham, J. W. (1986). Principled Organizational Dissent: A Theoretical Essay. Research in Organizational Behavior, 8, 1-52.

Hair, J. F. J., Hult, G. T. M., Ringle, C., \& Sarstedt, M. (2014). A Primer on Partial Least Squares Structural Equation Modeling (PLS-SEM). Long Range Planning (Vol. 46).

Hakim, T. I. R., Subroto, B., \& Andayani, W. (2017). Faktor Situasional dan Demografis sebagai Prediktor Niat Individu untuk Melakukan Whistleblowing. Jurnal Ilmiah Administrasi Publik, 3(2), 124-133. Retrieved from https://ejournalfia.ub.ac.id/index.php/jiap/article/download/684/980

Hanif, R. A., \& Odiatma, F. (2017). Pengaruh Personal Cost Reporting, Status Wrong Doer, dan Tingkat Keseriusan Kesalahan terhadap Whistleblowing Intention. Jurnal Akuntansi Keuangan Dan Bisnis, 10(1), 11-20.

Hatmoko, T. (2006). Pengaruh Kepuasan Kerja terhadap Komitmen Organisasi dan Pembedaannya terhadap Karakteristik. Demografik. (Studi Kasus di PDAM Kab. Karanganyar). Thesis, Universitas Sebelas Maret, Indonesia.

Hoffman, M. L. (1981). Is Altruism Part of Human Nature? Journal of Personality and Social Psychology, 40(1), 121-137. https://doi.org/10.1037//0022-3514.40.1.121

Hooks, K. L., Kaplan, S. E., Schultz, J. J., \& Ponemon, L. A. (1994). Enchancing Communication to Assist in Fraud Prevention and Detection. Auditing: A Journal of Practice \& Theory. 13 (2), 86-117. Retrieved from https://search.proquest.com/openview/2ab4224e7cc1854f1bd3c6d69415a8fb/1?pqorigsite $=$ gscholar\&cbl $=31718$

Husniati, S., Hardi, \& Wiguna, M. (2017). Faktor-faktor yang Mempengaruhi Intensi untuk Melakukan Whistleblowing Internal (Studi Empiris pada Satuan Kerja Perangkat Daerah Kabupaten Rokan Hulu). JOM Fekon, 4(1), 1223-1237.

Kaplan, S. E., \& Schultz, J. J. (2007). Intentions to Report Questionable Acts: An examination of The influence of Anonymous Reporting Channel, Internal Audit Quality, and Setting. Journal of Business Ethics, 71(2), 109-124. https://doi.org/10.1007/s10551-006-0021-6

King, G. (1997). The Effect of Interpersonal Closeness and Issue Seriousness on Blowing The Whistle. The Journal of Business Communication, 34(4), 419-436. https://doi.org/10.1177/002194369703400406

Kreshastuti, D. K., \& Prastiwi, A. (2014). Analisis Faktor-faktor yang Mempengarubi Intensi Auditor untuk Melakukan Tindakan Whistleblowing. Thesis, Universitas Diponegoro, Indonesia.

Lestari, R., \& Yaya, R. (2017). Whistleblowing dan Faktor-Faktor yang Mempengaruhi Niat Melaksanakannya oleh Aparatur Sipil Negara. Jurnal Akuntansi, 21(3), 336-350. https://doi.org/10.24912/ja.v21i3.265

Latane, B., \& Darley, J. M. (1968). Group Inhibition of Bystander Intervention in Emergencies. Journal of Personality and Social Psychology, 10(3), 215-221. https://doi.org/10.1037/h0026570

Libriani, E. W., \& Utami, I. (2015). Studi Eksperimental Tekanan Ketaatan dan Personal Cost: Dampaknya terhadap Whistleblowing. Jurnal Akuntansi Dan Bisnis, 15(2), 106 119. https://doi.org/10.20961/jab.v15i2.181

Menk, K. B. (2011). The Impact of Materiality, Personality Traits, and Ethical Position on Whistle-blowing Intentions. Retrieved from https://scholarscompass.vcu.edu/cgi/viewcontent.cgi? article $=3597 \&$ context $=$ etd 
Mesmer-Magnus, J. R., \& Viswesvaran, C. (2005). Whistleblowing in Organizations: An Examination of Correlates of Whistleblowing Intentions, Actions, and Retaliation. Journal of Business Ethics, 62(3), 277-297. https://doi.org/10.1007/s10551-005-0849-1

Miceli, M. P., \& Near, J. P. (1984). The Relationships among Beliefs, Organizational Position, and Whistle-Blowing Status: A Discriminant Analysis. The Academy of Management Journal, 27(4), 687-705. https://doi.org/10.2307/255873

Miceli, M. P., \& Near, J. P. (1985). Characterstics of Organizational Climate and Perceived Wrongdoing Associated with Whistle Blowing Decisions. Personnel Psychology, 38(3), 525-544. https://doi.org/10.1111/j.1744-6570.1985.tb00558.x

Miceli, M. P., \& Near, J. P. (1988). Individual and Situational Correlates of Whistle-Blowing. Personnel Psychology, 41(2), 267-281. https://doi.org/10.1111/j.17446570.1988.tb02385.x

Miceli, M. P., \& Near, J. P. (1992). Blowing The Whistle: The Organizational and Legal Implications for Companies and Employees. New York: Lexington Books.

Miceli, M. P., \& Near, J. P. (2005). Standing Up or Standing By: What Predicts Blowing on Organizational Wrongdoing. Research in Personnel and Human Resources Management, 24, 95-136. https://doi.org/10.1016/s0742-7301(05)24003-3

Miceli, M. P. (2004). Whistle-blowing Research and The Insider: Lessons Learned and Yet to Be Learned. Journal of Management Inquiry, 13(4), 364-366. https://doi.org/10.1177/1056492604270801

Miceli, M. P., Near, J. P., \& Dworkin, T. M. (2008). Whistle-blowing in Organizations. New York: Taylor \& Francis Group.

Miceli, M. P., Near, J. P., Rehg, M. T., \& van Scotter, J. R. (2012). Predicting Employee Reactions to Perceived Organizational Wrongdoing: Demoralization, Justice, Proactive Personality, and Whistle-blowing. Human Relations, 65(8), 923-954. https://doi.org/10.1177/0018726712447004

Miceli, M. P., Near, J. P., \& Schwenk, C. R. (1991). Who Blows the Whistle and Why? Industrial and Labor Relations Review, 45(1), 113-130. https://doi.org/10.2307/2524705

Miftah, T. (2012). Perilaku Organisasi: Konsep Dasar dan Aplikasinya. Jakarta: Rajawali Pers.

Mowday, R. T., Steers, R. M., \& Porter, L. W. (1979). The Measurement of Organizational Commitment. Journal of Vocational Behavior, 14, 224-247. https://doi.org/10.1016/0001-8791(79)90072-1

Nayir, D. Z., \& Herzig, C. (2012). Value Orientations as Determinants of Preference for External and Anonymous Whistleblowing. Journal of Business Ethics, 107(2), 197-213. https://doi.org/10.1007/s10551-011-1033-4

Near, J. P., \& Miceli, M. P. (1985). Organizational Dissidence: The Case of WhistleBlowing. Journal of Business Ethics, 4(1), 1-16. https://doi.org/10.1007/bf00382668

Near, J. P., \& Miceli, M. P. (1996). Whistle-blowing: Myth and Reality. Journal of Management, 22(3), 507-526. https://doi.org/10.1177/014920639602200306

Park, H., \& Blenkinsopp, J. (2009). Whistleblowing as Planned Behavior: A Survey of South Korean Police Officer. Journal of Business Ethics, 85(4), 545-556. https://doi.org/10.1007/s10551-008-9788-y

Phares, E. J., \& Wilson, K. G. (1972). Responsibility Attribution: Role of Outcome Severity, Situational Ambiguity, and Internal-External Control. Journal of Personality, 40(3), 392 406. https://doi.org/10.1111/j.1467-6494.1972.tb00069.x

Pillay, S., Ramphul, N., Dorasamy, N., \& Meyer, D. (2015). Predictors of Whistle-Blowing Intentions: An Analysis of Multi-Level Variables. Administration \& Society, 50(2), 186216. https://doi.org/10.1177/0095399715581621

Ponemon, L. A. (1994). Comment: Whistleblowing as an Internal Control Mechanism: Individual and Organizational Consideration. Auditing:A Journal of Practice \& Theory, 
118-130.

Porter, L. W., Steers, R. M., Mowday, R. T., \& Boulian, P. V. (1974). Organizational Commitment, Job Satisfaction, and Turnover Among Psychiatric Technicians. Joumal of Applied Psychology, 59(5), 603-609. https://doi.org/10.1037/h0037335

Robbins, S. (2007). Perilaku Organisasi. Edisi 1 Bahasa Indonesia. Jakarta: PT Indeks. Romney, M. B., \& Steinbart, P. J. (2015) Sistem Informasi Akuntansi. Jakarta: Salemba Empat. Said, J., Alam, M., Mohamed, D. I. B., \& Rafidi, M. (2017). Does Job Satisfaction, Fair Treatment, and Cooperativeness Influence The Whistleblowing Practice in Malaysian Government Linked Companies? Asian-Pacific Journal of Business Administration, 9(3), 220-231. https://doi.org/10.1108/apjba-06-2017-0053

Schultz, J. J., Johnson, D. A., Morris, D., \& Dyrnes, S. (1993). An Investigation of The Reporting of Questionable Acts in An International Setting. Journal of Accounting Research, 31, 75-103. https://doi.org/10.2307/2491165

Septianti, W. (2013). Pengarub Faktor Organisasional, Individual, Situasional, dan Demografis terhadap Niat Whistleblowing Internal. Paper was Presented at Simposium Nasional Akuntansi.

Setyawati, I., Ardiyani, K., \& Sutrisno, C. R. (2015). Faktor-faktor yang Mempengaruhi Niat untuk Melakukan Whistleblowing Internal (The Factors Influencing Internal Whistleblowing Intentions). Jurnal Ekonomi Dan Bisnis, 17(2), 22-33. Retrieved from http://jurnal.unikal.ac.id/index.php/jebi/article/viewFile/334/314

Street, M. D. (1995). Cognitive Moral Development and Organizational Commitment: Two Potential Predictors of Whistle-blowing. Journal of Applied Business Research, 10(4), 104 110. https://doi.org/10.19030/jabr.v11i4.5853

Vinten, G. (1996). Corporate Communications Through Whistleblowing. Corporate Communications: An International Journal, 1(1), 30-35. https://doi.org/10.1108/eb046523

Wahyuningsih, W. (2016). Pengaruh Pemberian Reward, Komitmen Organisasi, Gender, dan Masa Kerja terhadap Whistleblowing (Studi Empiris pada Kamtor PT. PLN (Persero) Wilayah Sumatra Barat). Jurnal Akuntansi, 4(1), 1-22. Retrieved from http://ejournal.unp.ac.id/students/index.php/akt/article/viewFile/2363/1872

Winardi, R. D. (2013). The influence of Individual and Situasional Factors on Lower-Level Civil Servants' Whistle-blowing Intention in Indonesia. Journal of Indonesian Economy and Business, 28(3), 361-376. Retrieved from https://journal.ugm.ac.id/jieb/article/download/6216/17781

Wispé, L. G. (1972). Positive Forms of Social Behavior: An Overview. Journal of Social Issues, 28(3), 1-19. https://doi.org/10.1111/i.1540-4560.1972.tb00029.x

\section{Regulation:}

Government regulation of Bureaucracy Reform Road Map 2010-2014 (Peraturan Menteri Pendayagunaan Aparatur Negara dan Reformasi Birokrasi Nomor 20 Tabun 2010 tentang Road Map Reformasi Birokrasi 2010-2014).

\section{Article in Website:}

Badan Pemeriksa Keuangan Republik Indonesia. (2017). Opini WTP dan Korupsi. www.bpk.go.id Accessed 12 December 2017.

Badan Pemeriksa Keuangan Perwakilan Provinsi Aceh. (2017). Pemerintah Aceh Raih WTP Kedua. www.bandaaceh.bpk.go.id Accessed 12 December 2017.

DetikNews. (2018). ICW: Korupsi Pengadaan Barang 2017 Meningkat, Negara Rugi Rp1 T. news.detik.com Accessed 11 March 2018.

Transparency International. (2013). Corruption Perceptions Index 2013. https://www.transparency.org/cpi2013/results Accessed 12 December 2017. 
Indriani, Yulia, Nadirsyah, \& Ariska

Whistleblowing Intention, Personal Cost, Organizational Commitment and Fraud Seriousness Level

Transparency International. (2014). Corruption Perceptions Index 2014.

https://www.transparency.org/cpi2013/results Accessed 12 December 2017.

Transparency International. (2015). Corruption Perceptions Index 2015.

https://www.transparency.org/cpi2013/results Accessed 12 December 2017.

Transparency International. (2016). Corruption Perceptions Index 2016.

https://www.transparency.org/cpi2013/results Accessed 12 December 2017. 